P-ISSN: 2774-4574; E-ISSN: 2774-4582 TRILOGI, 1(2), Sept - Des 2020 (56-71) @2020 Lembaga Penerbitan, Penelitian, dan Pengabdian kepada Masyarakat (LP3M) Universitas Nurul Jadid Paiton Probolinggo DOI: https://doi.org/

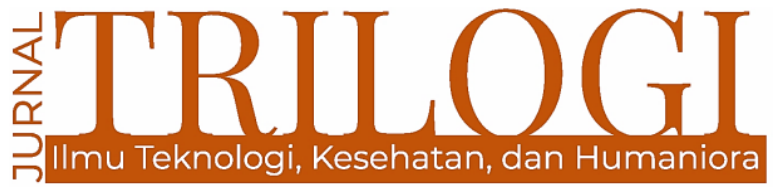

\title{
STRATEGI MEMBANGUN CITRA LEMBAGA PENDIDIKAN ISLAM: Peran Humas di Sekolah Menengah Pertama (SMP) Nurul Jadid Paiton Probolinggo
}

\author{
Fathor Rahman \\ Sekolah Tinggi Agama Islam Istiqlal, Buleleng, Bali \\ fathor.ampel288@gmail.com
}

\begin{abstract}
This study aims to describe the role of Public Relations in building an image and the methods used to promote Nurul Jadid Middle School, what media are used, what obstacles are there, and how to solve these obstacles. This research is a qualitative descriptive study. Research informants in this study were Public Relations Officer, Public Relations Coordinator, Promotion Officer and Principal. Data collection techniques using observation, interviews and documentation. The results showed that the role of public relations in building the image and promoting SMP Nurul Jadid, namely: 1 ) the role of public relations as a communicator to the internal public, namely students, employees/staff, teachers, and principals was carried out through official meetings and coordination meetings. While the external public, namely parents and guardians of students, DU/DI, the community, the Ministry of Manpower and PJTKI through parent meetings, committee meetings, collaboration with DU/DI, as well as collaboration with the Ministry of Manpower and PJTKI, 2) the role of public relations as a relationship builder, namely create good relations between all school members, the community, DU/DI, the Ministry of Manpower and PJTKI. Barriers to public relations, namely, 1) lack of enthusiasm from the community, 2) lack of cooperation with government agencies, 3) difficulty in finding places for internships, 4) limited budget or funds. Efforts to overcome obstacles are: 1) inviting and inviting community representatives, 2) seeking and establishing cooperation with government agencies in the implementation of internships, 3 ) establishing good communication with the community, 4) being polite and friendly to the community.
\end{abstract}

Keywords: public relation; image; SMP Nurul Jadid 


\begin{abstract}
Abstrak
Penelitian ini bertujuan mendeskripsikan peran Humas dalam membangun citra dan cara yang ditempuh dalam mempromosikan SMP Nurul Jadid, media apa saja yang digunakan, hambatan apa saja, dan bagaimana solusi mengatasi hambatan tersebut. Penelitian ini merupakan penelitian deskriptif kualitatif. Informan penelitian dalam penelitian ini adalah Petugas Humas, Koordinator Humas, Petugas Promosi dan Kepala Sekolah. Teknik pengumpulan data menggunakan observasi, wawancara dan dokumentasi. Hasil penelitian menunjukkan bahwa peran humas dalam membangun citra dan mempromosikan SMP Nurul Jadid yaitu: 1) peran humas sebagai komunikator terhadap publik internal yaitu siswa, karyawan/staf, guru, dan kepala sekolah dilakukan melalui rapat resmi dan rapat koordinasi. Sedangkan publik eksternal yaitu orang tua wali murid, DU/DI, masyarakat, Depnaker dan PJTKI melalui rapat wali murid, rapat komite, kerjasama dengan DU/DI, serta kerjasama dengan Depnaker dan PJTKI, 2) peran humas sebagai pembina hubungan (relationship) yaitu menciptakan hubungan yang baik antar seluruh warga sekolah, masyarakat, DU/DI, Depnaker dan PJTKI. Hambatan humas yaitu, 1) kurangnya antusias masyarakat, 2) kurangnya kerjasama dengan instansi-instansi pemerintah, 3) Sulitnya mencari tempat prakerin, 4) terbatasnya anggaran atau dana. Upaya mengatasi hambatan yaitu: 1) mengajak dan mengundang perwakilan masyarakat, 2) mencari dan menjalin kerjasama dengan instansi-instansi pemerintah dalam pelaksanaan prakerin, 3) menjalin komunikasi yang baik dengan masyarakat, 4) sopan santun serta ramah terhadap masyarakat.
\end{abstract}

Katakunci: humas; citra lembaga; SMP Nurul Jadid

\section{Pendahuluan}

Kepercayaan yang diberikan publik terhadap lembaga selalu mengalami pergeseran, hal ini disebabkan oleh tidak konsistenya lembaga dalam menjamin kualitas dan kuantitas lembaga sebagai penyedia jasa pendidikan, selain itu lembaga tidak mengalami perubahan dalam menghadapi persaingan diera modern, beberapa lembaga mengalami ketidak stabilan sehingga kepercayaan yang diberikan publik terhadap lembaga berkurang, dengan demikian lembaga harus memiliki trobosan baru dalam menghadapi persaingan secara global, untuk menjaga kelangsungan lembaga dan meningkatkan minat dan kepercayaan terhadap lembaga, ada beberpa hal yang perlu dilakukan lembaga untuk mengangkat citranya, upaya yang dapat dilakukan diantaranya lembaga harus selalu melakukan pengembangan disegala aspek sehingga lembaga terus bergerak maju, perkembangan tersebut tentunya harus terencana, terorganisir, terlaksana dan terevaluasi dengan baik.

Upaya mengangkat citra lembaga secara eksternal dapat dilakukan melaui dua hal yaitu secara koersif (paksaan) dan persuasive (membujuk), paksaan diartikan sebagai bentuk kewenangan lembaga yang didalamnya memuat aturan atura yang mengikat publiknya sehingga publik mengikuti kebijakan yang ditetapkan lembaga, sedangkan upaya persuasive (membujuk) adalah serangakaian upaya komunikasi yang berfungsi mempengaruhi psikologis publik melalui beberapa kegiatan seperti penyampaian informs secara lisan, ceramah, propaganda, lobbying yang ditujukan mempengaruhi cara pandang publik terhadap lembaga.

Persepsi publik terhadap lembaga tergantung pada siapa humas dan bagaimana karakter humas sebagai figur perwakilan lembaga yang dinaunginya, untuk itu humas dalam lembaga pendidikan harus memiliki bekal yang cukup dalam menghadapi publiknya, beberapa hal yang harus dimiliki seorang figure humas yaitu mampu meyakinkan penerima informasi, bersikap optimis, bersikap obyektif terhadap permasalahan, mampu menganalisis permasalahan dan merasionalkan permasalahan yang terjadi pada lembaga dan stakeholder-rnya, dan bertanggung jawab terhadap segala aktivitas informasi lembaga terhadap publiknya, dengan adanya sosok figur perwakilan lembaga terhadap publiknya humas harus mampu menjalankan strategi dengan baik, agar dalam pelaksanaan kegiatannya dapat terukur ketercapaiannya.

Fenomena yang terjadi saat ini tidak sedikit lembaga pendidikan negeri yang kalah bersaing dengan lembaga pendidikan swasta. salah satu faktornya adalah humas dalam lembaga pendidikan tersebut tidak dioptimalkan peran dan fungsinya. Selain hal tersebut fenomena yang terjadi adalah masyarakat mulai menggeser paradigmanya bahwa lembaga swasta jika dikelola dengan baik dapat mengalahkan eksistensi lembaga pendidikan negeri.

Lembaga pendidikan negeri seharusnya dapat lebih baik dibandingkan lembaga swasta dari segi pengelolaan, karena selain dari pada mayoritas guru yang berstatus pegawai negeri, fasilitas yang memadai dan adanya penyaringan masuk siswa 
yang ketat harusnya mampu lebih baik. Pendidikan merupakan sarana untuk memproduksi sumber daya manusia yang berkualitas, fenomena yang terjadi adalah biaya pendidikan bukan merupakan halangan yang berarti jika saja pendidikan yang diperoleh sebanding dengan apa yang diperoleh. Masyarakat mulai menyadari dan tidak terpaku dengan biaya pendidikan murah. Selain itu tidak sedikit lembaga pendidikan yang ditutup karena tidak dapat mempertahankan kepercayaan masyarakat yang diperoleh baik lembaga pendidikan negeri maupun swasta, dengan adanya fenomena tersebut peneliti melakukan riset di satu lembaga pendidikan negeri dan satu lembaga pendidikan swasta yang sudah teruji memiliki citra yang baik dan mampu membangun kepercayaan, mempertahankan kepercayaan, dan mampu mengangkat citra lembaganya, dengan persamaan karakteristik kedua lembaga tentunya ada perbedaan dalam membangun citra baik lembaga, untuk itu peneliti mengangkat judul "Strategi Membangun Citra Lembaga Pendidikan Islam: Studi Kasus pada Peran Humas di SMP Nurul Jadid Paiton Probolinggo", judul tersebut begitu penting diangkat karena pada dasarnya kepercayaan masyarakat dan pencitraan terhadap lembaga pendidikan merupakan bentuk kepuasan layanan produsen terhadap konsumennya.

\section{Method}

Jenis penelitian ini adalah penelitian deskriptif kualitatif. Penelitian ini bermaksud menyajikan data secara sistematis dan akurat mengenai faktafakta dan fenomena yang ada di lapangan. Penelitian ini bermaksud untuk menelaah hal-hal yang berhubungan dengan peranan humas dalam rangka membangun citra dan cara mempromosikan atau memasarkan SMP Nurul Jadid terhadap masyarakat luas. Instrumen penelitian ini meliputi:

\section{Observasi}

Observasi merupakan kegiatan pengamatan dan pencatatan sistemik terhadap segala hal yang terjadi di lapangan. Observasi dalam penelitian ini dimaksudkan untuk melakukan pengamatan terhadap kondisi sekolah, rencana program kerja SMP Nurul Jadid, media komunikasi dan media hubungan masyarakat baik secara internal maupun eksternal.

\section{Wawancara}

Teknik wawancara adalah proses memperoleh keterangan dengan cara tanya jawab secara langsung dengan narasumber. Proses wawancara menggunakan alat berupa pedoman wawancara yang berisi permasalahan pokok. Isi pedoman wawancara berupa pertanyaan-pertanyaan yang bertujuan menggali data maupun informasi sebanyakbanyaknya dan sedalam-dalamnya kepada responden. Data maupun informasi yang ingin peneliti ketahui yaitu latar belakang dibentuknya humas SMP Nurul Jadid, pelaksanaan proses humas, peran humas sebagai komunikator, peran humas dalam menjalin hubungan dan peran humas dalam membentuk citra serta bagaimana cara mempromosikan SMP Nurul Jadid kepada masyarakat

\section{Dokumentasi}

Dokumentasi merupakan teknik pengumpulan data dengan cara mengumpulkan dokumendokumen yang dapat mendukung data yang diperoleh melalui observasi dan wawancara. Dokumen-dokumen tersebut berupa denah SMP Nurul Jadid, sejarah SMP Nurul Jadid, Visi dan Misi SMP Nurul Jadid, struktur organisasi, brosur dan lain sebagainya.

\section{Hasil dan Pembahasan}

\subsection{Hasil Penelitian}

\section{Gambaran Umum Humas di SMP Nurul Jadid}

Kepala Sekolah SMP Nurul Jadid memiliki empat wakil kepala sekolah (waka). Empat waka tersebut yaitu Waka bidang kurikulum, kesiswaan, humas dan sarana prasarana. Waka bidang humas di SMP Nurul Jadid ini dijabat oleh Bapak Ahmad Ismail, S.Pd yang bertugas untuk mengarahkan serta melaksanakan tugas pokok, wewenang dan tanggung jawab humas itu sendiri. Pelaksanaan tugas humas tidak hanya dilakukan oleh Bapak Ismail sendiri, namun juga bersama guru-guru lainnya.

Pelaksanaan kegiatan humas di SMP Nurul Jadid berperan penting pada saat promosi menjelang penerimaan peserta didik baru (PPDB) dan dalam kegiatan menjalin komunikasi dengan warga sekolah dan masyarakat sekitar. Menjelang waktu pengumuman lulusan siswa SMP dan mendekati waktu pendaftaran SMA/SMK. SMP Nurul Jadid membentuk panitia penerimaan peserta didik baru (PPDB). Di dalam kepanitiaan tersebut terdapat bagian yang bertanggung jawab penuh pada kegiatan promosi sekolah. Panitia yang bertanggung jawab dalam kegiatan promosi tersebut akan melakukan promosi berupa sosialisasi ke SMP-SMP di Probolinggo dan sekitarnya.

\section{Peran Humas sebagai Communicator}

Peran humas sebagai communicator (komunikator) di SMP Nurul Jadid diwujudkan dalam berbagai kegiatan yang dilakukan oleh sekolah dalam mencapai tujuan sekolah itu sendiri. Selain untuk mencapai tujuan sekolah, pentingnya peranan humas sebagai komunikator juga untuk tujuan memperoleh kepercayaan publik baik internal maupun eksternal terhadap SMP Nurul Jadid. Berdasarkan hasil wawancara dengan Kepala Sekolah 
SMP Nurul Jadid diketahui bahwa terdapat peran humas sebagai komunikator terhadap publik internal maupun ekstenal. Oleh karena itu perlu dibentuk adanya pengurus humas sekolah. Pemilihan pengurus humas menurut Kepala Sekolah SMP Nurul Jadid haruslah memenuhi karakteristik seorang petugas humas. Kepala Sekolah SMP Nurul Jadid menyatakan bahwa:

"untuk menjadi pengurus humas faktor terpenting adalah kemampuan berkomunikasi dengan baik atau smart communication, mampu menjalin hubungan baik dan juga berwawasan luas".

Pelaksanaan peran humas di SMP Nurul Jadid sebagai komunikator dibedakan menjadi 2, yaitu sebagai komunikator terhadap publik internal dan publik eksternal.

\section{1) Publik Internal}

\section{a) Siswa}

Publik internal adalah para warga sekolah, yang terdiri dari seluruh siswa, guru-guru, dan karyawan serta kepala sekolah. Sesuai dengan yang dikemukakan oleh Ibu Eny Puji Astuti, S.Pd sebagai berikut: "yang menjadi sasaran humas di SMP Nurul Jadid ya seluruh warga sekolah seperti siswa, guru, karyawan dan masyarakat." Pelaksanaan kegiatan humas tidak akan berjalan baik tanpa adanya respon positif dari siswa itu sendiri.

Komunikasi yang dilakukan humas kepada siswa diantaranya adalah berupa penyampaian informasi bahwa SMP Nurul Jadid akan mengadakan program penerimaan peserta didik baru (PPDB) tahun ajaran 2015/2016. Tujuan dari para siswa diberitahu akan adanya program tersebut adalah untuk mengajak sanak saudara, teman atau tetangga mereka untuk bersekolah di SMP Nurul Jadid.

Humas sekolah juga menyampaikan kepada siswa kelas XI semua jurusan terkait dengan pelaksanaan Praktek Kerja Industri (Prakerin) di Dunia Usaha/Dunia Industri (DU/DI). Pelaksanaan Prakerin dilakukan pada semester genap selama duduk dikelas XI. Pelaksanaan prakerin dilakukan di wilayah Probolinggo, Sleman dan Bantul.

Pada siswa kelas XII humas menyampaikan bahwa SMP Nurul Jadid memiliki Bursa Kerja Khusus (BKK) yang bekerja sama dengan Depnaker Probolinggo dan Perusahaan Jasa Tenaga Kerja Indonesia (PJTKI). Kerjasama yang dibentuk sekolah dengan Depnaker Probolinggo dan
Perusahaan Jasa Tenaga Kerja Indonesia (PJTKI) berupa penyaluran informasi lowongan pekerjaan yang masuk di Depnaker Probolinggo dan Perusahaan Jasa Tenaga Kerja Indonesia (PJTKI) untuk disampaikan kepada siswa SMP Nurul Jadid yang akan segera lulus.

Selain informasi-informasi tersebut disampaikan kepada siswa, humas juga selalu memberikan bimbingan kepada seluruh siswanya agar selalu menaati seluruh peraturan yang berlaku di SMP Nurul Jadid. Siswa juga diberitahu terkait pelaksanaan Ujian Akhir Semester (UAS) dan Ujian Kenaikan Kelas (UKK).

\section{b) Guru dan Karyawan}

Humas SMP Nurul Jadid tidak hanya menyampaikan informasi kepada siswa saja. Namun informasi juga disampaikan kepada guru maupun karyawan SMP Nurul Jadid. Penyampaian informasi tersebut dilakukan pada saat rapat koordinasi yang diadakan setiap hari Senin dan 2 minggu sekali dalam rapat waka. Keterangan tersebut diperoleh dari Bapak Arofik selaku kepala sekolah sebagai berikut:

"Pemantauan saya terhadap jalannya proses kegiatan humas di SMP Nurul Jadid ini saya lakukan melalui rapat koordinasi dan rapat Waka yang dilaksanakan setiap 2 minggu 1 kali. Pada rapat bersama Waka itu nanti, setiap Waka menyampaian kegiatan yang sudah terlaksana dan belum terlaksana, serta menyampaikan kendala-kendala yang dihadapi".

Informasi yang disampaikan berupa informasi mengenai pelaksanaan rapat atau agenda terdekat yang akan diadakan di SMP Nurul Jadid.

Selain kegiatan yang ada di dalam sekolah, humas juga menyampaikan informasi terkait dengan kegiatan kekeluargaan atau insidental seperti menjenguk keluarga guru yang sakit, hajatan, atau takziyah bersama. Komunikasi antar guru dan karyawan dilakukan secara langsung dan melalui media telepon selular atau HP. Oleh karena itu sekolah menganjurkan agar setiap guru dan karyawan memiliki nomor HP yang aktif dan dapat dihubungi.

\section{c) Kepala Sekolah}

Informasi yang disampaikan oleh humas kepada guru dan karyawan merupakan hasil persetujuan dengan Kepala Sekolah. Setiap 2 minggu sekali, 
kepala sekolah mengadakan rapat koordinasi dengan Wakil Kepala Sekolah (Waka) kurikulum, humas, kesiswaan dan sarpras. Melalui rapat koordinasi tersebut, humas dapat menyampaikan berbagai informasi yang diterima kepada Kepala Sekolah untuk ditindak lanjuti.

Berdasarkan penjelasan pada masingmasing sasaran publik internal tersebut maka kegiatan yang dilakukan humas SMP Nurul Jadid sebagai komunikator yaitu :

Pertama, Penyampaian segala informasi sekolah secara tatap muka langsung kepada siswa mulai dari kelas VII sampai kelas IX. Penyampaian pemberitahuan tersebut selain melalui rapat juga dilakukan melalui surat edaran atau surat pemberitahuan resmi.

Kedua, Rapat Koordinasi. Rapat koordinasi yang dilakukan setiap hari senin yang dilaksanakan oleh seluruh guru dan karyawan sekolah terkait pelaksanaan kegiatan sekolah.

Ketiga, Rapat Waka. Rapat Waka adalah rapat yang dilakukan Kepada Sekolah bersama dengan Wakil Kepala Sekolah setiap 2 minggu sekali. Rapat ini bertujuan untuk mengetahui bagaimana laporan pelaksanaan seluruh kegiatan yang akan dan sudah dilaksanakan. Selain itu rapat ini sekaligus pemantauan yang dilakukan Kepala Sekolah terhadap tanggung jawab pelaksanaan tugas dari masing-masing Waka.

2) Publik Eksternal

a) Orang tua atau Wali Murid

Peranan humas SMP Nurul Jadid sebagai komunikator juga dilakukan kepada orang tua atau wali murid. Kegiatan komunikator dengan wali murid dilakukan pada saat rapat bersama wali murid yang biasanya dilaksanakan pada waktu awal memasuki sekolah, menjelang ujian kenaikan kelas, menjelang ujian nasional, pada saat penerimaan rapor dan kegiatan lain sebagainya. Hal tersebut sesuai dengan pernyataan Bapak Butro, S.Pd sebagai berikut:

"Kalau sama publik internal ya informasi tentang pelaksanaan rapat, ujian, agenda sekolah, dan acara-acara insidental. Sedangkan kalau sama publik eksternal ya informasi pelaksanaan PPDB, informasi pelaksanaan ujian semester, ujian nasional, pelaksanaan promosi ke SMP-
SMP di sekitar Probolinggo, dan sebagian di Situbondo dan Bondowoso."

Selain melalui pertemuan langsung dengan wali murid, penyampaian informasi kepada wali murid juga dilakukan melalui surat edaran atau surat pemberitahuan. Informasi yang disampaikan kepada wali murid diantaranya adalah informasi mengenai standar minimal lulusan siswa, jadwal ujian bagi siswa, informasi pembayaran sekolah serta tata tertib yang perlu ditaati siswa.

\section{b) $D U / D I$}

DU/DI adalah dunia usaha dan dunia industri yang akan dijadikan tempat dilaksanakannya kegiatan prakerin siswa kelas VIII. Humas bekerjasama dengan kepala kompetensi keahlian yang ada di SMP Nurul Jadid menginformasikan kepada DU/DI bahwa SMP Nurul Jadid ingin bekerjasama dengan DU/DI dalam rangka pelaksanaan kegiatan pelaksanaan prakerin SMP Nurul Jadid kelas VIII selama 3 bulan.

c) Masyarakat

Pelaksanaan komunikasi humas SMP Nurul Jadid sebagai komunikator kepada masyarakat yaitu bahwa humas menyampaikan kepada masyarakat jika suatu hari SMP Nurul Jadid akan mengadakan acara yang menimbulkan kebisingan dan kemungkinan akan mengganggu kenyamanan warga sekitar sekolah. Oleh karena itu pihak SMP Nurul Jadid meminta ijin kepada masyarakat sekitar. Selain itu, kegiatan penyampaian informasi kepada masyarakat juga dilakukan pada saat rapat bersama dengan komite sekolah, kepala sekolah, guru, dan serta mengundang masyarakat sekitar sekolah.

Berdasarkan penjelasan pada masingmasing sasaran publik eksternal di atas maka kegiatan yang dilakukan humas SMP Nurul Jadid sebagai komunikator kepada publik eskternal yaitu:

a) Rapat wali murid

Rapat wali murid adalah rapat yang diselenggarakan sekolah bersama dengan wali murid. Biasanya rapat ini diselenggarakan pada awal memasuki sekolah, menjelang ujian akhir semester, ujian nasional, menjelang kelulusan siswa, dan lain sebagainya. Rapat ini bertujuan untuk menyampaikan segala bentuk informasi yang ada di sekolah yang erat kaitannya dengan siswa agar wali murid dapat mengetahui informasi tersebut. 
b) Kerjasama dengan DU/DI

DU/DI adalah kependekan dari Dunia Usaha/ Dunia Industri. DU/DI adalah tempat siswa kelas VIII melakukan kegiatan praktek kerja industri. Sebelum pelaksanaan praktek kerja industri (prakerin) yang dilaksanakan oleh siswa kelas VIII, sekolah perlu menghubungi pihak DU/DI yang akan dijadikan tempat prakerin. Pencarian tempat prakerin sepenuhnya dilimpahkan kepada masingmasing ketua kompetensi keahlian.

c) Rapat Komite Sekolah

Rapat komite sekolah adalah rapat yang dilakukan sekolah bersama dengan komite sekolah. Pada pelaksanaan rapat komite sekolah turut serta melibatkan beberapa masyarakat sekitar sekolah untuk mengikuti rapat tersebut. Dalam rapat tersebut disampaikan berbagai rancangan program kerja sekolah, hal ini bertujuan agar masyarakat dapat mengetahui program-program sekolah.

3. Humas sebagai Pembina Hubungan

Humas berperan sebagai pembina hubungan (relationship). Pada pelaksanaannya, humas SMP Nurul Jadid menjalin hubungan baik dengan orang tua siswa/wali murid, masyarakat, antar guru dalam sekolah, dengan DU/DI dan dengan Depnaker serta PJTKI. Dalam menjalin hubungan, SMP Nurul Jadid menjalin hubungan dengan publik internal dan juga publik eksternal.

Hubungan dengan publik internal dilakukan dengan orang tua siswa/wali murid. Hubungan yang dibina yaitu dengan cara selalu memberikan berbagai pemberitahuan terkait dengan informasi tentang standar minimal lulusan, jadwal ujian bagi siswa, tata tertib sekolah, perkembangan siswa di sekolah dan informasi kegiatan sekolah lainnya. Selain dengan orang tua/wali siswa, sekolah juga membina hubungan baik dengan sesama guru dan karyawan di SMP Nurul Jadid dengan tujuan agar dapat meminimalisir adanya konflik di dalam sekolah yang dapat menghambat pencapaian tujuan SMP Nurul Jadid.

Selain membina hubungan baik dengan publik internal, humas SMP Nurul Jadid juga membina hubungan dengan masyarakat sekitar sekolah. Hubungan tersebut berupa mengikut sertakan masyarakat sekitar sekolah untuk ikut serta dalam rapat yang dilaksanakan oleh sekolah bersama dengan komite sekolah. Tujuan mengajak masyarakat sekitar dalam rapat bersama komite sekolah adalah agar masyarakat mengetahui dengan jelas apa sajakan kegiatan yang dilaksanakan oleh SMP Nurul Jadid. Hal tersebut sesuai dengan pernyataan Bapak Ahmad Ismail, S.Pd sebagai berikut:

" .....untuk

masyarakat

luas, penyampaian informasi menggunakan brosur atau poster serta turut mengundang perwakilan dari masyarakat untuk mengikuti rapat komite sekolah agar masyarakat mengetahui program-program kegiatan yang ada di sekolah".

Selain dengan orang tua siswa, guru dan karyawan SMP Nurul Jadid dan masyarakat sekitar, SMP Nurul Jadid juga membina hubungan dengan DU/DI dan Depnaker serta PJTKI. Hubungan bersama dengan DU/DI dilakukan oleh humas dan kepala jurusan masing-masing jurusan di SMP Nurul Jadid.

Hubungan kerjasama dengan DU/DI bertujuan untuk menjadikan DU/DI tersebut sebagai tempat pelaksanaan praktik kerja industri siswa kelas XI. Kemudian kerjasama bersama dengan Depnaker dan PJTKI berupa kerjasama untuk memperoleh informasi mengenai lowongan kerja untuk disampaikan kepada siswa kelas XII atau lulusan SMP Nurul Jadid.

\section{Peran Humas sebagai Pembangun Citra}

Peran humas sebagai Pembangun citra SMP Nurul Jadid belum terlihat. Sejauh ini belum ada kegiatan nyata yang dilakukan SMP Nurul Jadid dalam membentuk opini atau kepercayaan publik terhadap SMP Nurul Jadid. Upaya yang dilakukan SMP Nurul Jadid guna memperoleh opini atau kepercayaan publik yaitu baru sebatas menjalin komunikasi yang baik, bersikap ramah tamah kepada masyarakat, mengadakan kegiatan bersama dengan dengan masyarakat, dan menyampaikan kepada masyarakat terkait berbagai kegiatan di SMP Nurul Jadid melalui rapat bersama dengan komite sekolah.

Kegiatan SMP Nurul Jadid yang pernah dilaksanakan bersama dengan masyarakat sekitar sudah terjadi sangat lama dan belum diadakan kembali saat ini. Hal tersebut dikarenakan terbatasnya dana yang dimiliki oleh SMP Nurul Jadid.

5. Peran Humas dalam Mempromosikan SMP Nurul Jadid

Peranan humas SMP Nurul Jadid dalam rangka mempromosikan SMP Nurul Jadid ada berbagai macam. Kegiatan promosi yang dilakukan, yaitu : pemasangan spanduk/banner SMP Nurul Jadid, sosialisasi ke SMP-SMP di Probolinggo dan sekitarnya, promosi dari mulut ke mulut, penyebaran brosur, dan informasi pendaftaran di website SMP Nurul Jadid. Sebelum pelaksanaan kegiatan promosi SMP Nurul Jadid tersebut dilakukan, maka sekolah terlebih dahulu membentuk susunan panitia 
pelaksanaan kegiatan promosi. Panitia kegiatan promosi tersebut dikoordinir oleh Waka Humas. Penjelasan masing-masing kegiatan promosi yang dilakukan SMP Nurul Jadid yaitu sebagai berikut:

\section{1) Pemasangan banner}

Kegiatan pemasangan banner ini dilakukan di tempat-tempat yang mudah terbaca oleh pengguna jalan raya. Seperti di pinggir jalan besar, di dekat lampu lalu lintas dan terutama di sekitar SD/MI sekitar Probolinggo. Pemasangan banner tersebut dilakukan oleh Bapak-bapak guru/karyawan SMP Nurul Jadid yang telah ditunjuk sebagai Sie Perlengkapan.

2) Presentasi sekaligus sosialisasi ke SD/MI di Probolinggo dan sekitarnya.

Kegiatan presentasi sekaligus sosialisasi ke SD/MI tersebut dilakukan pada saat waktu siswa kelas VI menunggu hasil UN mereka. Sebelum melaksanakan sosialisasi dihadapan siswa SD/MI kelas VI terlebih dahulu SMP Nurul Jadid membuat surat ijin untuk melaksanakan sosialisasi di sekolah tersebut. Jika diijinkan, maka SMP Nurul Jadid akan segera menentukan jadwal sosialisasi tersebut. Pelaksanaan kegiatan ini dilakukan oleh Sie Promosi yang telah ditunjuk sebelumnya. Kegiatan presentasi sekaligus sosialisasi tidak hanya dilakukan pada satu sekolah saja, namum ke beberapa sekolah, maka tidak menutup kemungkinan bahwa akan ada suatu hari pelaksanaan sosialisasi dalam waktu yang bersamaan. Oleh karena itu, jika terdapat waktu yang bersamaan maka tim sosialisasi dibagi menjadi beberapa kelompok.

\section{3) Promosi dari mulut ke mulut}

Kegiatan promosi dari mulut ke mulut maksudnya adalah kegiatan promosi yang dilakukan melalui siswa-siswa yang telah masuk ke SMP Nurul Jadid untuk mengajak saudara, teman atau tetangga mereka untuk masuk ke SMP Nurul Jadid. Cara ini dianggap mampu untuk memenuhi kuota yang dibutuhkan oleh sekolah.

\section{4) Penyebaran brosur}

Kegiatan penyebaran brosur dilakukan di SD/MI dan SMP yang berada di sekitar SMP Nurul Jadid. Penyebaran brosur di SD/MI bersamaan pada saat kegiatan sosialisasi berlangsung, sedangkan penyebaran brosur di SMK lain pada saat hari-hari pendaftaran siswa didik baru dengan sasarannya pada siswa yang tidak diterima di SMK tersebut. Penyebaran brosur dilakukan oleh panitia yang telah ditunjuk sebelumnya.

5) Melalui Website

Informasi mengenai penerimaan peserta didik baru (PPDB) di SMP Nurul Jadid tidak hanya dilakukan melalui proses sosialisasi atau tatap muka secara langsung dengan calon siswa. Penyampaian informasi terkait PPDB juga disampaikan melalui website SMP Nurul Jadid. Informasi yang terdapat pada website antara lain adalah jurusan atau program studi yang ada di SMP Nurul Jadid, waktu pendaftaran, dan persyaratan yang harus dibawa pada saat mendaftar. Tujuan penyampaian informasi PPDB melalui website ini adalah agar masyarakat atau calon siswa yang tidak memperoleh brosur atau kurang memperoleh informasi dapat memperoleh informasi hanya dengan membuka website melalui layanan internet.

\section{Penggunaan Media Komunikasi}

Pelaksanaan peran humas dalam rangka membangun citra dan mempromosikan SMP Nurul Jadid tidak terlepas dari adanya penggunaan media komunikasi. Pada pelaksanaan kegiatan-kegiatan humas menggunakan berbagai media. Mediamedia tersebut berupa media cetak maupun media elektronik.

Berdasarkan hasil observasi dan wawancara yang dilakukan, maka dapat diketahui bahwa SMP Nurul Jadid menggunakan beberapa media komunikasi dalam pelaksanaan kegiatannya. Media komunikasi yang digunakan yaitu:

\section{1) Komunikasi Langsung}

Komunikasi langsung merupakan komunikasi yang dilakukan dengan cara bertatap muka langsung. Komunikasi ini dilakukan dimana komunikator dan komunikan saling berhadapan. Komunikasi langsung yang dilakukan di SMP Nurul Jadid yaitu: rapat resmi, rapat koordinasi, rapat wali murid, rapat komite sekolah, presentasi dan sosialisasi sekolah.

2) Komunikasi Tidak Langsung

Komunikasi tidak langsung adalah komunikasi yang dilakukan dengan menggunakan bantuan media tertentu. Media tersebut dapat berupa media cetak atau media elektronik. Media tersebut yaitu:

a) Brosur 
Brosur adalah lembaran kertas promosi terkait informasi pendaftaran siswa tahun ajaran baru yang akan dibagikan kepada siswa-siswi SMP yang akan memasuki SMA/SMK.

b) Poster dan spanduk

Poster SMP Nurul Jadid adalah infomasi mengenai PPDB yang memuat profil SMP Nurul Jadid dan syarat-syarat pendaftaran menjadi siswa baru. Sedangkan spanduk juga memuat informasi yang sama. Spanduk dapat berupa sebuah banner dengan ukuran besar yang dipasang pada tempat-tempat yang mudah dibaca oleh masyarakat.

c) Telepon

Telepon merupakan media komunikasi yang digunakan oleh SMP Nurul Jadid guna menyampaian dan menerima informasi singkat secara cepat. Telepon ini menggunakan jaringan telekomunikasi.

d) Surat Resmi

Surat adalah sarana komunikasi yang sudah ada sejak dahulu. Surat resmi ditandai dengan adanya kepala surat berupa logo dan nama sekolah, serta adanya tandatangan kepala sekolah dan cap asli SMP Nurul Jadid. Surat resmi digunakan untuk menjalin komunikasi dengan orang tua siswa, DU/DI, komite sekolah, Depnaker, PJTKI, dan masyarakat.

e) E-mail

Selain surat resmi, komunikasi juga dapat dilakukan melalui surat elektronik yang disebut e-mail. E-mail SMP Nurul Jadid yaitu smpnj@gmail.com

f) Website

Untuk lebih meninggkatkan penyebaran informasi berbagai kegiatan di SMP Nurul Jadid, maka SMP Nurul Jadid menggunakan website sebagai medianya. Alamat website SMP Nurul Jadid yaitu www.smpnuruljadid.sch.id

\section{Hambatan Humas SMP Nurul Jadid}

1) Hambatan humas sebagai komunikator Pelaksanaan peran humas SMP Nurul Jadid sebagai komunikator kepada publik internal hingga saat ini berjalan dengan lancar. Sedangkan peran humas sebagai komunikator kepada publik eksternal terdapat beberapa hambatan. Hambatan yang dihadapi dalam proses komunikasi dengan publik eksternal adalah kurangnya antusias masyarakat terhadap SMP Nurul Jadid karena SMP Nurul Jadid merupakan sekolah swasta. Hambatan lainnya adalah kurangnya kerjasama dengan instansi-instansi pemerintah terkait pelaksanaan prakerin siswa kelas IX.

2) Hambatan humas dalam membina hubungan

Pelaksanaan peran humas SMP Nurul Jadid dalam membina hubungan saat ini belum berjalan secara lancar dan maksimal. Hal tersebut dikarenakan sekolah mengalami kesulitan dalam mencari dan menjalin kerjasama dengan instansi-instansi pemerintah guna pelaksaan prakerin. Kesulitan yang dihadapi dalam mencari tempat prakerin terutama untuk jurusan akuntansi dan administrasi perkantoran.

3) Hambatan humas dalam membangun citra SMP Nurul Jadid

Pelaksanaan peran humas SMP Nurul Jadid hingga saat ini belum dapat berjalan dengan baik. Hal tersebut dikarenakan terbatasnya anggaran atau dana serta kurangnya antusias masyarakat terhadap SMP Nurul Jadid yang berstatus sekolah swasta. Masyarakat beranggapan bahwa sekolah swasta kurang mampu menghasilkan lulusan yang berkualitas.

4) Hambatan humas dalam mempromosikan SMP Nurul Jadid

Kegiatan mempromosikan SMP Nurul Jadid dilakukan oleh humas SMP Nurul Jadid dan panitia promosi pelaksanaan PPDB SMP Nurul Jadid. Pelaksanaan promosi SMP Nurul Jadid yang dilakukan oleh panitia PPDB tersebut berupa pelaksanaan sosialisasi ke SMP-SMP di Probolinggo dan sekitarnya. Hambatan pelaksanaan sosialisasi tersebut diantaranya adalah bahwa ada beberapa SD di Probolinggo yang menolak secara terang-terang adanya kegiatan sosialisasi tersebut. Itu artinya tim promosi SMP Nurul Jadid tidak diijinkan untuk melaksanakan kegiatan sosialisasi. Hambatan yang selanjutnya adalah bahwa pada pelaksanaan sosialisasi dengan siswa SD yaitu bahwa siswa-siswi SD tidak tertarik dan antusias dengan presentasi dari tim SMP Nurul Jadid.

8. Upaya yang Dilakukan dalam Mengatasi Hambatan

1) Upaya humas mengatasi hambatan sebagai komunikator

Upaya humas SMP Nurul Jadid dalam mengatasi hambatan yang dihadapi 
sebagai komunikator dalam perananya terhadap publik eksternal yaitu selalu mengajak dan mengundang perwakilan dari masyarakat sekitar SMP Nurul Jadid untuk mengikuti rapat koordinasi bersama dengan komite sekolah. Dalam rapat tersebut SMP Nurul Jadid akan menyampaikan terkait pelaksanaan kegiatan-kegiatan yang telah dilaksanakan oleh SMP Nurul Jadid

2) Upaya humas mengatasi hambatan sebagai pembina hubungan

Upaya humas SMP Nurul Jadid dalam mengatasi hambatan yang dihadapi sebagai pembina hubungan yaitu sekolah lebih berusaha mencari dan menjalin kerjasama dengan instansiinstansi pemerintah dalam pelaksanaan prakerin. Hal tersebut bertujuan agar siswa-siswa dapat memperoleh tempat prakerin yang sesuai dengan program keahliannya masing-masing, khususnya untuk jurusan akuntansi dan administrasi perkantoran

3) Upaya humas mengatasi hambatan dalam membangun citra SMP Nurul Jadid

Upaya humas SMP Nurul Jadid dalam mengatasi hambatan yang terjadi dalam membangun citra SMP Nurul Jadid adalah selalu menjalin komunikasi yang baik dengan masyarakat. Komunikasi yang baik terutama pada masyarakat di sekitar SMP Nurul Jadid. Komunikasi yang baik dimulai dengan cara yang sederhana, yaitu selalu bersikap sopan dan santun serta ramah terhadap masyarakat. Selain itu siswa selalu diberi nasehat bahwa tidak diperbolehkan untuk merusak atau bersikap negatif terhadap masyarakat

4) Upaya humas mengatasi hambatan dalam mempromosikan SMP Nurul Jadid

Upaya humas dan panitia PPDB SMP Nurul Jadid dalam mengatasi hambatan yang dialami pada saat sosialisasi tentang SMP Nurul Jadid kepada siswa SMP yaitu membuat suasana presentasi dengan suasana yang menyenangkan agar siswa tidak merasa bosan, kemudian SMP Nurul Jadid akan memberikan reward atau hadiah kepada siswa yang aktif bertanya serta berpartisipasi dalam kegiatan sosialiasasi tersebut. Kemudian untuk sekolah yang secara terang-terangan menolak adanya kegiatan sosialisasi SMP Nurul Jadid tersebut, maka untuk tahun-tahun berikutnya sekolah tersebut tidak akan dimasukkan ke dalam daftar sekolah yang akan dituju pada kegiatan sosialisasi.

\subsection{Pembahasan}

1. Peran Humas SMP Nurul Jadid sebagai Communicator

Communicator (komunikator) merupakan salah satu bagian terpenting dalam komponen komunikasi. Komponen komunikasi ada 6, yaitu: sumber, komunikator, pesan atau informasi, media, komunikan, dan umpan balik (feedback). Tanpa adanya komunikator suatu informasi atau pesan tidak akan tersampaikan kepada komunikan. Suatu informasi perlu disampaikan kepada komunikan agar suatu tujuan komunikasi tersebut berjalan dengan baik, serta tujuan dari penyampaian informasi tersebut dapat terpenuhi.

Sebuah sekolah pasti memiliki visi, misi serta tujuan yang berbeda-beda. Namun, walaupun visi, misi dan tujuannya berbeda yang terpenting adalah maksud dari adanya sekolah tersebut sama, yaitu mencerdaskan kehidupan bangsa. Agar tujuan-tujuan sekolah dapat tercapai, maka perlu adanya kerja keras dari seluruh warga sekolah. Pencapaian tujuan sekolah tersebut tidak lepas dari adanya komunikasi yang dilakukan oleh seluruh warga sekolah. Oleh karena itu, komunikasi merupakan faktor penting dalam usaha pencapaian tujuan sekolah itu sendiri. Jika komunikasi merupakan faktor penting dalam pencapaian tujuan, itu berarti komunikator yang merupakan komponen komunikasi juga faktor terpenting.

Pelaksanaan peran humas sebagai komunikator sangatlah penting, dimana dengan adanya humas segala informasi yang terdapat di sekolah dapat disampaikan kepada sasaran humas. Sasaran humas meliputi publik internal dan publik eksternal. Peran humas sebagai komunikator kepada publik internal adalah menyampaikan segala informasi yang perlu diketahui oleh seluruh warga sekolah, yaitu adanya pelaksanaan rapat, pembentukan panitia PPDB, pembinaan OSIS, pelaksanaan agenda sekolah dan informasi lainnya. Sedangkan pelaksanaan peranan humas kepada publik ekternal meliputi penyampaian informasi mengenai kegiatan sekolah kepada masyarakat sekitar dan komite sekolah, penyampaian informasi kepada DU/DI terkait waktu pelaksanaan praktek kerja industri, serta penyampaian kepada calon alumni (siswa kelas XII) bahwa SMP Nurul Jadid bekerjasama dengan Depnaker Probolinggo dan PJTKI jika terdapat lowongan pekerjaan.

2. Peran Humas SMP Nurul Jadid sebagai Pembina Hubungan

Membina hubungan (relationship) adalah kegiatan yang dilaksanakan oleh suatu lembaga atau organisasi dengan 
khalayaknya. Pentingnya membina hubungan suatu organisasi dengan khalayaknya yaitu untuk dapat melancarkan dalam proses pencapaian tujuan dari lembaga atau organisasi tersebut. Suatu lembaga atau organisasi mempunyai berbagai tujuan yang ingin dicapai. Demikian juga dengan SMP Nurul Jadid yang mempunyai berbagai maksud dan tujuan dalam membina hubungan baik dengan khalayaknya. Tujuan sekolah antara lain adalah dapat menciptakan citra positif sekolah, mendapatkan kerjasama yang baik dengan masyarakat, wali murid, DU/DI dan dengan Depnaker serta PJTKI. Kemudian SMP Nurul Jadid juga menciptakan suasana yang kondusif di lingkungan sekolah.

Hubungan kerjasama antara sekolah dengan masyarakat guna menciptakan citra positif sekolah yaitu dengan cara menjalin komunikasi yang baik dengan masyarakat. Masyarakat dalam hal ini adalah masyarakat di sekitar sekolah. Hubungan baik dengan masyarakat diwujudkan SMP Nurul Jadid dengan beberapa cara. Cara tersebut antara lain selalu bersikap ramah terhadap masyarakat, ketika membawa kendaraan di lingkungan sekitar sekolah tidak seenaknya, tetap menaati tata tertib lalu lintas, dan selalu memberikan pemberitahuan jika SMP Nurul Jadid mengadakan kegiatan yang melibatkan dan berdampak pada masyarakat.

Hubungan kerjasama antara sekolah dengan wali murid dapat dilihat dengan adanya komunikasi yang lancar. Komunikasi lancar antara sekolah dengan wali murid dilaksanakan melalui rapat wali murid, pada saat terima rapor dan pada saat menjelang kelulusan siswa serta melalui surat edaran/pemberitahuan. Dengan adanya komunikasi yang baik antara sekolah dan wali murid diharapkan akan meminimalisir adanya konflik yang terjadi antara pihak sekolah dan pihak orang tua murid.

Hubungan kerjasama antara sekolah dengan DU/DI adalah dengan adanya pelaksanaan kegiatan prakerin. Adanya kegiatan prakerin dapat memberikan keuntungan kedua belah pihak. Keuntungan yang diperoleh oleh DU/DI dengan adanya siswa prakerin adalah dapat membantu terselesaikannya pekerjaan yang terdapat di DU/DI tersebut. Sedangkan keuntungan yang diperoleh sekolah adalah siswa dapat mengaplikasikan kemampuannya di DU/DI tempat prakerin.

Hubungan yang dibina oleh SMP Nurul Jadid tersebut adalah hubungan dengan publik eksternal. Namun, SMP Nurul Jadid juga membina hubungan baik dengan publik internalnya. Publik internal yaitu seluruh warga sekolah, mulai dari kepala sekolah, guru, karyawan, dan siswa. Dalam menciptakan suasana hubungan yang harmonis antara kepala sekolah, guru, dan karyawan di SMP Nurul Jadid diwujudkan dengan cara setiap guru dan karyawan saling membantu dalam proses kegiatan sekolah, bersama-sama dalam menasehati siswa yang kurang tertib, serta adanya kegiatan silaturahmi yang terjalin dengan baik sesama keluarga masing-masing. Misalnya dengan menghadiri acara atau hajatan, menjenguk anggota keluarga yang sakit, dan lain-lain. Sedangkan hubungan baik yang diciptakan dengan siswa yaitu selalu menjadi pendengar yang baik atas segala keluh kesah siswa. Siswa dapat menceritakan masalah-masalah yang sedang dihadapi dengan guru atau karyawan sekolah lainnya.

3. Peran humas sebagai Pembangun citra (corporate image)

Peran humas sebagai Pembangun citra (corporate image) adalah peranan humas dalam rangka menumbuhkan citra SMP Nurul Jadid di mata masyarakat. Citra positif merupakan bagian dari tujuan SMP Nurul Jadid. Pentingnya citra positif masyarakat terhadap SMP Nurul Jadid akan sangat mempengaruhi seluruh program kerja di SMP Nurul Jadid.

Citra atau kesan positif masyarakat terhadap SMP Nurul Jadid dapat diartikan sebagai kepercayaan publik terhadap SMP Nurul Jadid. Kepercayaan yang dimaksudkan adalah kepercayaan masyarakat untuk bersekolah atau menyekolahkan anak-anaknya ke SMP Nurul Jadid. Oleh karena itu, karena pentingnya pembentukan citra tersebut, SMP Nurul Jadid mengerahkan segenap pihak guna membentuk kesan positif masyarakat tersebut. Pengaruh citra atau kesan positif dari masyarakat tersebut dapat memberikan dorongan semangat atau motivasi serta dukungan dari berbagai pihak terkait dengan proses kegiatan yang ada di SMP Nurul Jadid.

Berdasarkan hasil wawancara yang diperoleh maka hal-hal yang dilakukan SMP Nurul Jadid dalam membentuk citra positif dari masyarakat ada beberapa cara. Beberapa cara yang ditempuh adalah dengan bersikap sopan, santun, ramah terhadap masyarakat, serta menyampaikan segala informasi profil SMP Nurul Jadid kepada masyarakat luas.

4. Peran Humas dalam Mempromosikan SMP Nurul Jadid

Promosi merupakan suatu kegiatan memasarkan atau memperkenalkan suatu produk atau jasa kepada masyarakat luas. Promosi sekolah adalah kegiatan mempromosikan keberadaan suatu 
lembaga pendidikan kepada masyarakat, agar masyarakat mengetahui dan menerima adanya sekolah tersebut. Tujuan kegiatan promosi sekolah adalah agar sebuah sekolah dapat dikenal oleh masyarakat luas. Jika sebuah sekolah sudah banyak dikenal masyarakat, terutama dikenal dengan kesan yang positif maka sekolah tersebut secara otomatis akan menarik minat siswa untuk sekolah di sekolah tersebut. Proses promosi terdapat 6 cara yang perlu ditempuh, yaitu Komunikasi personal dan interpersonal (telemarketing, customer service \& training, word of mouth), Periklanan, Promosi penjualan Publisitas/hubungan masyarakat, Peralatan instruksional dan Corporate Design.

Strategi promosi yang dilakukan oleh SMP Nurul Jadid yang pertama kali adalah pemasangan banner atau spanduk SMP Nurul Jadid, pada banner tercantum kompetensi keahlian serta akreditasi masing-masing kompetensi keahlian tersebut. Strategi yang kedua adalah mengumumkan kepada siswa SMP Nurul Jadid untuk mengajak saudara, kerabat, atau tetangga mereka untuk masuk sekolah ke SMP Nurul Jadid.

Strategi ketiga yaitu presentasi sekaligus sosialisasi ke SD-SD di sekitar Probolinggo, Bantul dan Sleman. Sebelum presentasi dan sosialisasi tersebut dilakukan maka SMP Nurul Jadid mengirimkan surat ke SD guna meminta ijin untuk melakukan presentasi dan sosialisasi tersebut. Jika diijinkan, maka SMP Nurul Jadid dan SD yang bersangkutan segera mengatur jadwal pelaksanaan presentasi dan sosialisasi. Dalam kegiatan presentasi, tim promosi menyampaikan beberapa hal terkait SMP Nurul Jadid. Halhal yang disampaikan antara lain : profil sekolah, alamat sekolah, visi misi dan tujuan sekolah, macam-macam beasiswa, macam-macam ekstrakurikuler, dan prospek siswa setelah lulus sekolah. Selama kegiatan presetasi dan sosialisasi tersebut siswa diberi brosur sekolah, dan setelah presentasi selesai maka dibuka sesi tanya jawab. Bagi siswa yang aktif bertanya maka akan diberikan reward dari tim promosi.

Strategi keempat adalah pengumuman PPDB di website SMP Nurul Jadid. Pengumuman dalam website berisi tentang waktu dan tempat pendaftaran, kompetensi keahlian yang ada di SMP Nurul Jadid. Selain itu juga terdapat beberapa syaratsyarat yang perlu dibawa ketika mendaftar.

Pelaksanaan kegiatan promosi yang dilakukan SMP Nurul Jadid tersebut sudah hampir sesuai dengan 6 strategi yang tersebut di atas. Komunikasi personal dan interpersonal (telemarketing, customer service \& training, word of mouth) yang dilakukan tim promosi SMP Nurul Jadid yaitu penyampaian segala informasi mengenai SMP Nurul Jadid kepada masyarakat luas dan penyampaian pada saat presentasi dan sosialisasi. Periklanan yang dilakukan oleh SMP Nurul Jadid yaitu pemasangan banner dan pembagian brosur. Promosi penjualan yang dilakukan adalah kegiatan presentasi mengenai prospek luluan SMP Nurul Jadid setelah lulus sekolah nantinya. Publisitas/hubungan masyarakat yang dilakukan oleh SMP Nurul Jadid adalah dengan kegiatan presentasi dan sosialisasi yang dilakukan di SMP-SMP di sekitar Probolinggo, Bantul, dan Sleman. Peralatan instruksional yang digunakan oleh SMP Nurul Jadid adalah menggunakan media berupa LCD Proyektor dalam kegiatan presentasi dan sosialisasi. Sedangkan Corporate design sejauh ini belum sepenuhya dilakukan dengan baik. Pelaksanaan corporate design di SMP Nurul Jadid baru sebatas pada pemasangan logo sekolah pada banner, brosur, spanduk, dan segaram sekolah.

\section{Penggunaan Media Komunikasi}

Pelaksanaan peran humas dalam rangka membangun citra dan mempromosikan SMP Nurul Jadid tidak terlepas dari adanya penggunaan media komunikasi. Pada pelaksanaan kegiatan-kegiatan humas menggunakan berbagai media. Mediamedia tersebut berupa media cetak maupun media elektronik.

Berdasarkan hasil observasi dan wawancara yang dilakukan, maka dapat diketahui bahwa SMP Nurul Jadid menggunakan dua bentuk komunikasi dalam pelaksanaan kegiatannya. Komunikasi yang digunakan yaitu :

\section{a. Komunikasi Langsung}

Komunikasi langsung merupakan komunikasi yang dilakukan dengan cara bertatap muka langsung. Komunikasi ini dilakukan dimana komunikator dan komunikan saling berhadapan. Komunikasi langsung yang dilakukan di SMP Nurul Jadid yaitu: rapat resmi, rapat koordinasi, rapat wali murid, rapat komite sekolah, presentasi dan sosialisasi sekolah. Pada kegiatan rapatrapat tersebut disampaikan hal-hal yang berkaitan dengan seluruh program kerja sekolah. Sedangkan presentasi dan sosialisasi dilakukan oleh tim promosi sekolah kepada siswa-siswi SMP yang akan memasuki jenjang pendidikan SMA/SMK.

\section{b. Komunikasi Tidak Langsung}

Komunikasi tidak langsung adalah komunikasi yang dilakukan dengan menggunakan bantuan media tertentu. Media tersebut dapat berupa media 
cetak atau media elektronik. Media komunikasi tidak langsung yang digunakan SMP Nurul Jadid yaitu brosur, poster, spanduk, surat resmi, telepon, email, dan website.

6. Hambatan Pelaksanaan Humas SMP Nurul Jadid

a. Hambatan humas sebagai komunikator Hambatan yang dihadapi dalam proses komunikasi dengan publik eksternal adalah kurangnya antusias masyarakat terhadap SMP Nurul Jadid karena SMP Nurul Jadid merupakan sekolah swasta. Hambatan lainnya adalah kurangnya kerjasama dengan instansi-instansi pemerintah terkait pelaksanaan prakerin siswa kelas XI.

b. Hambatan humas dalam membina hubungan

Pelaksanaan peran humas SMP Nurul Jadid dalam membina hubungan saat ini belum berjalan secara lancar dan maksimal. Sekolah mengalami kesulitan dalam mencari dan menjalin kerjasama dengan instansi-instansi pemerintah guna pelaksanaan prakerin. Kesulitan yang dihadapi dalam mencari tempat prakerin terutama untuk jurusan akuntansi dan administrasi perkantoran.

c. Hambatan humas dalam membangun citra SMP Nurul Jadid

Hambatan humas dalam membangun citra yakni terbatasnya anggaran atau dana serta kurangnya antusias masyarakat terhadap SMP Nurul Jadid yang berstatus sekolah swasta. Masyarakat beranggapan bahwa sekolah swasta kurang mampu menghasilkan lulusan yang berkualitas.

d. Hambatan humas dalam mempromosikan SMP Nurul Jadid

Hambatan pelaksanaan promosi di SDSD yang pertama adalah bahwa ada beberapa SD di Probolinggo yang menolak secara terang-terang adanya kegiatan sosialisasi. Kemudian hambatan yang kedua yaitu siswa-siswi SD tidak tertarik dan antusias dengan presentasi dari tim SMP Nurul Jadid.

7. Upaya Mengatasi Hambatan Humas SMP Nurul Jadid

a. Upaya humas mengatasi hambatan sebagai komunikator

Upaya humas SMP Nurul Jadid dalam mengatasi hambatan yang dihadapi sebagai komunikator dalam perannya terhadap publik eksternal yaitu selalu mengajak dan mengundang perwakilan dari masyarakat sekitar SMP Nurul Jadid untuk mengikuti rapat bersama dengan komite sekolah.

b. Upaya humas mengatasi hambatan sebagai pembina hubungan

Upaya humas SMP Nurul Jadid dalam mengatasi hambatan yang dihadapi sebagai pembina hubungan yaitu sekolah lebih berusaha mencari dan menjalin kerjasama dengan instansiinstansi pemerintah dalam pelaksanaan prakerin.

c. Upaya humas mengatasi hambatan dalam membangun citra SMP Nurul Jadid.

Upaya humas SMP Nurul Jadid dalam mengatasi hambatan yang terjadi dalam membangun citra SMP Nurul Jadid adalah selalu menjalin komunikasi yang baik dengan masyarakat. Selalu bersikap sopan dan santun serta ramah terhadap masyarakat. Selain itu siswa selalu diberi nasehat bahwa tidak diperbolehkan untuk merusak atau bersikap negatif terhadap masyarakat.

d. Upaya humas mengatasi hambatan dalam mempromosikan SMP Nurul Jadid.

Upaya humas dan panitia PPDB SMP Nurul Jadid dalam mengatasi hambatan yang dialami pada saat sosialisasi tentang SMP Nurul Jadid kepada siswa SD yaitu menciptakan suasana presentasi dengan suasana yang menyenangkan agar siswa tidak merasa bosan, kemudian SMP Nurul Jadid akan memberikan reward atau hadiah kepada siswa yang aktif bertanya serta berpartisipasi dalam kegiatan sosialisasi tersebut. Sekolah yang secara terangterangan menolak adanya kegiatan sosialisasi SMP Nurul Jadid tersebut, maka untuk tahun-tahun berikutnya sekolah tersebut tidak akan dimasukkan ke dalam daftar sekolah yang akan dituju pada kegiatan sosialisasi.

\section{Penutup}

Berdasarkan hasil penelitian dan pembahasan mengenai peran humas dalam membangun citra dan mempromosikan SMP Nurul Jadid, maka dapat ditarik kesimpulan sebagai berikut:

1. Peran humas dalam rangka membangun citra dan mempromosikan SMP Nurul Jadid secara keseluruhan belum berjalan secara baik, yakni: 1) peran humas sebagai komunikator terhadap publik internal yaitu siswa, karyawan/staf, guru, dan kepala sekolah dilakukan melalui rapat resmi, surat resmi dan rapat koordinasi. Sedangkan dengan publik eksternal yaitu orang tua wali murid, DU/DI, masyarakat, 
Depnaker dan PJTKI melalui rapat wali murid, rapat komite, kerjasama dengan DU/DI, serta kerjasama dengan Depnaker dan PJTKI, 2) peran humas sebagai pembina hubungan (relationship) yaitu menciptakan hubungan yang baik antar seluruh warga sekolah, membina hubungan baik dengan masyarakat, menjalin kerjasama dengan DU/DI terkait pelaksanaan prakerin, namun usaha kerjasama tersebut belum berjalan baik karena masih kesulitan memperoleh tempat prakerin untuk jurusan AP dan AK, menjalin kerjasama dengan Depnaker dan PJTKI agar memperoleh informasi mengenai lowongan pekerjaan bagi para lulusan, namun hingga saat ini belum ada data jelas tentang keterserapan lulusan. 3) peran humas dalam menbangun citra SMK yaitu selalu membina siswa dan seluruh warga sekolah untuk bersikap sopan, santun, ramah dan tamah kepada seluruh masyarakat, terutama masyarakat yang berada di lingkungan sekolah, menciptakan lingkungan yang kondusif di sekolah, meningkatkan kualitas pendidikan dan pelayanan yang baik terhadap masyarakat. 4) peran humas dalam mempromosikan SMP Nurul Jadid yaitu pemasangan banner, presentasi serta sosialisasi ke SMP-SMP di Probolinggo dan sekitarnya, promosi dari mulut ke mulut, penyebaran brosur, dan informasi pendaftaran di website SMP Nurul Jadid.

2. Media yang digunakan humas dalam membangun citra dan mempromosikan SMP Nurul Jadid melalui media komunikasi langsung dan komunikasi tidak langsung. Media komunikasi langsung yang digunakan humas SMP Nurul Jadid berupa kegiatan rapat resmi, rapat koordinasi, rapat komite sekolah, rapat wali murid, presentasi dan sosialisasi sekolah ke SMP-SMP. Sedangkan media komunikasi tidak langsung meliputi media cetak dan media elektronik, diantaranya: brosur, poster, spanduk (banner), telepon,e-mail, dan website.

3. Hambatan Pelaksanaan Humas SMP Nurul Jadid dalam perannya sebagai komunikator, pembina hubungan, pembentuk citra dan mempromosikan SMP Nurul Jadid yaitu : 1) kurangnya antusias masyarakat terhadap SMP Nurul Jadid karena SMP Nurul Jadid merupakan sekolah swasta, 2) kurangnya kerjasama dengan instansi-instansi pemerintah terkait pelaksanaan prakerin siswa kelas XI, 3) Sekolah mengalami kesulitan dalam mencari dan menjalin kerjasama dengan instansiinstansi pemerintah guna pelaksanaan prakerin, 4) terbatasnya anggaran atau dana, 5) ada beberapa SMP di Kulon Progo yang menolak secara terang-terang adanya kegiatan sosialisasi.

4. Upaya yang dilakukan humas dalam mengatasi hambatan sebagai komunikator, pembina hubungan, pembentuk citra dan mempromosikan SMP Nurul Jadid yaitu: 1) mengajak dan mengundang perwakilan dari masyarakat sekitar SMP Nurul Jadid untuk mengikuti bersama dengan komite sekolah, 2) lebih berusaha mencari dan menjalin kerjasama dengan instansi-instansi pemerintah dalam pelaksanaan prakerin, 3) selalu menjalin komunikasi yang baik dengan masyarakat, 4) Selalu bersikap sopan dan santun serta ramah terhadap masyarakat, 5) menciptakan suasana presentasi dengan suasana yang menyenangkan agar siswa tidak merasa bosan, kemudian SMP Nurul Jadid akan memberikan reward atau hadiah kepada siswa yang aktif berpartisipasi.

\section{Referensi}

Daniel Yadin. 2003. Public Relations (Frank Jeknis. Terjemahan) London : Indonesia. Jakarta: Erlangga.

Dita Rahmawati Iriyanti. 2014. Peran Humas dalam Memberikan Pelayanan kepada Pelanggan di Perusahaan Daerah Air Minum (PDAM) Tirtamarta Yogyakarta. Skripsi. Pendidikan Administrasi Perkantoran. FE UNY

Emzir. 2012. Metodologi Penelitian Kualitatif: Analisis Data. Jakarta: Rajawali Press

Fajar Widyastuti. 2012. Peran Humas dalam Membangun Citra Sekolah Menengah Kejuruan Negeri 4 Yogyakarta. Skripsi. Pendidikan Administrasi Perkantoran FISE UNY

Firsan Nova. 2011. CRISIS : Public Relations. Jakarta : PT Raja Grafindo Persada.

Frida Kusumastuti. 2002. Dasar-Dasar Hubungan Masyarakat. Jakarta : Ghalia Indonesia.

Haris Munandar. 1992. Public Reltions (Frank Jeknis. Terjemahan) London : Indonesia. Jakarta : Bumi Aksara.

Mukhtar \& Iskandar. 2009. Orientasi Baru Supervisi Pendidikan. Jakarta : Gaung Persada

Mulyasa Dedi. 2012. Pendidikan Bermutu Berdaya Saing. Bandung: PT. Remaja Rosdakarya.

Muslimin. 2004. Hubungan Masyarkat dan Konsep Kepribadian. Malang : UMM Press

Ngalim Purwanto. 2005. Administrasi dan Supervisi Pendidikan. Bandung : PT Remaja Rosdakarya.

Oemi Abdurrachman. 1993. Dasar-Dasar Public Relation. Bandung : Citra Aditya Bakti.

Peraturan Menteri RI Nomor 17 tahun 2010 tentang Pengelolaan dan Penyelenggaraan pendidikan

Rachmadi F.1992. Public Relations Dalam Teori Dan Praktek, Jakarta: Gramedia. 
Rosady Ruslan. 2005. Kampanye Public Relations.Jakarta : PT Rajagrafindo Persada

2012. Manajemen Public Relations \& Media Komunikasi. Jakarta : PT Raja Grafindo Persada.

Soleh Soemirat dan Elvinaro, Ardianto. 2008. Dasar-Dasar Public Relations. Bandung: PT Remaja Rosdakarya.

Suharsimi Ari Kunto dan Lia Yuliana. 2008. Manajemen Pendidikan. Yogyakarta: Aditya Media bekerjasma dengan Fakultas Ilmu Pendidikan Universitas Negeri Yogyakarta.

Suranto Aw. 2005. Komunikasi Perkantoran. Yogyakarta: Media Wacana
Suryosubroto B. 1988. Humas dalam Dunia Pendidikan. Yogyakarta : Mitra Gama Widya

Tim Dosen Administrasi Pendidikan Universitas Pendidikan Indonesia. 2011. Manajemen Pendidikan. Bandung : Alfabeta

Widjaja A.W. 1993. Komunikasi dan Hubungan Masyarakat. Jakarta : Bumi Aksara

Yosal Irianta dan Yani Surachman. 2006. Public Relations Writing Pendekatan Teoritis dan Praktis. Bandung: Simbiosa Rekatama Media

Zulkarnain Nasution. 2010. Manajemen Humas di Lembaga Pendidikan. Malang: Universitas Muhammadiyah Malang Press. 